\title{
Surgical treatment of Chagas megacolon. Critical analysis of outcome in operative methods ${ }^{1}$
}

\author{
Tratamento cirúrgico do megacólon chagásico análise crítica dos resultados dos \\ métodos operatórios
}

\author{
Ricardo Luiz Santos Garcia', Bruna Meyer R. de Matos ${ }^{\mathrm{II}}$, Omar Féres ${ }^{\mathrm{III}}$ José Joaquim Ribeiro da Rocha $^{\mathrm{IV}}$ \\ I MD, Fellow PhD degree, Division of Coloproctology, Department of Surgery and Anatomy, Ribeirão Preto Faculty of Medicine, \\ University of São Paulo, Brazil. \\ II MD, Resident, Department of Surgery and Anatomy, Ribeirão Preto Faculty of Medicine, University of São Paulo, Brazil. \\ ${ }^{\text {III }}$ PhD, Professor, Division of Coloproctology, Department of Surgery and Anatomy, Ribeirão Preto Faculty of Medicine,University of \\ São Paulo, Brazil. \\ Iv PhD, Professor, Division of Coloproctology, Department of Surgery and Anatomy, Ribeirão Preto Faculty of Medicine,University of \\ São Paulo, Brazil.
}

\begin{abstract}
Purpose: Surgical treatment of chagasic megacolon has suffered innumerable transformations over the years. Poor knowledge of the disease physiopathology is one of the reasons. Methods: From January 1977 to December 2003, 430 patients were submitted to surgical treatment for chagasic megacolon. Of these procedures, 351 were elective and 79 emergency operations carried out at the University Hospital of Ribeirão Preto. Four elective operations, most frequently used, should be singled out: anterior rectosigmoidectomy (52.71\%), left hemicolectomy (18.23\%), Duhamel-Haddad operation(15.95\%), and total colectomy (5.98\%). From the 79 exploratory laparotomies performed on an emergency basis, $53(67.09 \%)$ required intestinal resection. From the 430 patients operated upon, $268(62.33 \%)$ progressed without recurrence of intestinal constipation, and $71(15.51 \%)$ had a recurrence. Results and Discussion: Based on the data collected, left hemicolectomy had the highest constipation recurrence rate compared to other operating procedures; anterior retosigmoidectomy had less complication episodes and a larger recurrence of intestinal constipation in comparison to the Duhamel-Haddad operation. Emergency operations, mainly for the treatment of volvulus and fecaloma, presented high morbidity and mortality and required extensive intestinal resections, stomas and reoperations.
\end{abstract}

Key words: Chagasic Megacolon. Chagas Disease. Surgical Treatment.

\section{RESUMO}

Introdução: $\mathrm{O}$ tratamento cirúrgico do megacólon chagásico tem passado por sucessivas modificações ao longo do tempo. A multiplicidade das operações é explicada pelo conhecimento ainda incompleto da fisiopatologia da doença, Métodos: No período de janeiro de 1977 a dezembro de 2003, 430 pacientes chagásicos foram submetidos a tratamento cirúrgico para o megacólon no Hospital das Clínicas de Ribeirão Preto. Foram realizadas 351 operações eletivas e 79 de urgência. Quatro tipos de operações realizadas em caráter eletivo mereceram destaque por terem sido as mais utilizadas: retossigmoidectomia anterior $(52,71 \%)$, hemicolectomia esquerda $(18,23 \%)$, abaixamento de cólon à Duhamel-Haddad $(15,95 \%)$ e colectomia total (5,98\%). Das 79 laparotomias exploradoras realizadas em regime de urgência, em 53 (67,09\%) houve ressecção intestinal. Dentre os 430 pacientes operados, 268 (62,33\%) evoluíram sem recidiva e 71 (16,51\%) com recidiva da constipação intestinal. Resultados e Discussão: Com base nos resultados obtidos concluiu-se que: a hemicolectomia esquerda, comparada às demais operações, apresentou maior recidiva da constipação intestinal; a retossigmoidectomia anterior comparada à operação de Duhamel-Haddad apresentou menor número de complicações e maior recidiva da constipação intestinal; as operações de urgência para o tratamento do volvo e do fecaloma apresentaram alta morbimortalidade, exigem resseções intestinais, estomas e reoperações.

Descritores: Megacólon Chagásico. Doença de Chagas. Tratamento Cirúrgico.

1. Study performed in the Division of Coloproctology of the Department of Surgery and Anatomy of Ribeirão Preto Faculty of Medicine, University of São Paulo, Brazil. 


\section{Introduction}

Surgical treatment of chagasic megacolon has suffered innumerable transformations over the years. Poor knowledge of the disease physiopathology is one of the reasons for the diverse operation procedures as well as the complication indexes related to them, and last but not least, the difficulties in long term post-surgery following.

\section{Historical data}

Assuming that colon dilatation was the main cause of the disease, surgeons in the past practiced sigmoidectomy, resecting only the dilated colon portion and keeping the rectum and colon portion, which macroscopically looked normal. ${ }^{1-3}$

In the 1930, in the period of the sphincter achalasia theory, Correa Neto was favorable to resection of the socalled functional colon sphincters. ${ }^{4,5}$ The initial operation procedures based on the achalasia concept sectioned the internal anus or pelvis-rectal sphincters.

The achalasia concept was gradually substituted by the one of "distal intestine dyskenesia" considering rectal or distal functional obstruction, which differs from achalasia by the greater extension of the affected intestinal segment.

During 1947 to 1952, rectosigmoidectomy was the operation of choice but it was substituted in later years, to 1958 , by abdominoperineal rectosigmoidectomy with immediate colorectal anastomosis. The modification was meant to reduce infection incidence in the pre-sacral space and dehiscence of the anastomotic suture, but specially to verify its interference in sphincteral continence and sexual function, possibly existing in lowerings due to rectum cancer. $^{6}$

From 1959 on, abdominoperineal rectosigmoidectomy with retarded colorectal anastomosis (Cutait operation) was the procedure utilized. The technique was widely publicized not only in Brazil but also in Latin America. By increasing resection of the dyskenetic rectum it aimed to reduce recurrence indexes and prevent or reduce to a minimum the possibility of dehiscence on the anastomotic suture line, a frequent occurrence in immediate colorectal anastomosis. An improved maintenance of the perineal muscular system constituted by the levatores and internal and external anus sphinters was also considered in the development of the Cutait operation, which in addition avoided a transversostomy and decreased hospitalization. ${ }^{7}$

The surgical procedure proposed by Duhamel for congenital megacolon was divulged by Bernardes de Oliveira as a surgical treatment for Chagas megacolon. ${ }^{8,9}$

The Duhamel procedure was partially modified by Haddad, Raia and Correa Neto ${ }^{10}$ and from 1966, utilizing the variation proposed by Haddad, was the tecnique mostly used by Brazilian surgeons.

In cases of extensive megacolon, Vasconcelos ${ }^{11}$ indicated subtotal colectomy with ceco-rectal anastomosis.
Capelhuchnik ${ }^{12,13}$ started using left hemicolectomy while Lins Neto adopted immediate colorectal anastomosis as an improvement in the Duhamel procedure. Although showing morbidity and mortality comparable and sometimes inferior to national averages for the Duhamel-Haddad operation, this procedure decreased hospitalization and costs. It utilized manual anastomosis as well as a mechanical one employing a linear cutting stapler. ${ }^{14,15}$

Since 1989, a new surgical approach was idealized by Habr-Gama consisting of abdominal rectosigmoidectomy with immediate posterior end-to side mechanical colorectal anastomosis. This operation with a final configuration similar to the Duhamel procedure was also adopted by Nahas and is applied in one single surgical event. ${ }^{16-18}$

The videolaparoscopic technique employed mainly by Brazilian surgeons for the treatment of Chagas megacolon, is the Duhamel procedure conducted in a single surgical event. ${ }^{19-21}$

\section{Objective}

To evaluate results with the different operation methods utilized in the treatment of Chagas megacolon in 430 patients admitted to the University Hospital of the Faculty of Medicine of Ribeirao Preto from January, 1977 to December 2003.

\section{Methods}

This retrospective study was registered at the Ministry of Health authorized by the Committee on Ethics in Research and conducted at the University Hospital of the Faculty of Medicine of Ribeirao Preto-University of São Paulo (HCFMRP-USP).

The 430 patients included in this report were diagnosed as having Chagas megacolon and were operated on, electively or as an emergency, during the period of January, 1977 and December 2003. They were aged between 20-91 years, average 57.58 years, $236(54.88 \%)$ were males and $194(45.12 \%)$ females. In relation to race, $363(84.42 \%)$ were whites, $45(10.46 \%)$ mulattos, $20(4.66 \%)$ negro and 2 $(0.46 \%)$ Asian.

Elective surgical techniques in relation to the presence or absence of complications were initially compared by the Chi square $\left(\mathrm{X}^{2}\right)$ method, with a significance level of $\mathrm{p} \leq 0.05$. For individual comparison of elective surgical techniques the Chi square method was also employed. Considering the Bonferroni correction, significant differences were only with $\mathrm{p} \leq 0.01$.

Post-surgical complications were scored from 1 to 3 according to gravity: light, moderate or severe (Table 1). The non- parametric Kruskal-Wallis and the post hoc Dunn tests with $\mathrm{p} \leq 0.05$ were applied in the analysis of elective operations according to the complication levels. Emergency operations and laparotomies with and without intestinal resection were analyzed and compared according to complication severity by the non-parametric Mann Whitney test. 
TABLE 1 Post-surgery complications evaluated according to severity

\section{Complications}

Anastomosis dehiscence with peritonitis Pré-sacral abcess

Rectal segment dehiscence

Ischemia and necrosis of the lowered colon

Death

Blocked anastomotic dehiscence

Anastomosis stenosis

Dehiscence of the abdominal wall

Anastomosis bleeding to the colon lumen

Intestinal obstruction by bridas

Alteration of fecal continence

Sexual alterations

Fecaloma of the rectal segment

Incisional hernia

\section{Evaluation}

severe

severe

Severe

severe

severe

Moderate

Moderate

moderate

moderate

moderate

moderate

moderate

moderate

light
Recurrence of post-surgery intestinal constipation was compared between the diverse elective surgical techniques through the Chi square test with $\mathrm{p} \leq 0.05$. The Chi square and the exact Fischer tests were employed for individual comparisons of surgical procedures in relation to recurrence. Considering the Bonferroni correction, only differences with $\mathrm{p} \leq 0.01$ were considered significant.

\section{Results}

Chronic progressive intestinal constipation, refractory to clinical treatment, was the prevailing cause in 351 patients submitted to elective surgery. Sigmoid volvulus, which cannot be undone endoscopiscally, was the main indication for emergency surgery in 48 patients. Other emergency procedures were due to intestinal fecaloma obstruction, ischemic colitis and iatrogenic perforation of the rectosigmoid (Table 2).

TABLE 2 - Surgical alternatives.

\begin{tabular}{|c|c|c|}
\hline Operation & $\mathbf{n}^{\mathbf{o}}$ & $(\%)$ \\
\hline ELECTIVE & 351 & $(81,63)$ \\
\hline Intestinal constipation refractory to treatment & & 351 \\
\hline EMERGENCY & 79 & $(18,37)$ \\
\hline Sigmoid volvulus & 48 & $(11,16)$ \\
\hline Without ischemia & & 21 \\
\hline With ischemia & & 23 \\
\hline Without perforation & & 14 \\
\hline With perforation & & 9 \\
\hline Total colon ischemia & & 4 \\
\hline Fecaloma (Intestinal obstruction) & 13 & $(3,02)$ \\
\hline Without sigmoid ischemia & & 4 \\
\hline With sigmoid necrotic ischemia & & 7 \\
\hline With right colon necrotic ischemia & & 1 \\
\hline With total colon ischemia & 1 & \\
\hline Ischemic Colitis & 8 & $(1,86)$ \\
\hline Iatrogenic sigmoid perforation & 10 & $(2,33)$ \\
\hline TOTAL & 430 & $(100,0)$ \\
\hline
\end{tabular}

Of the 351 elective surgery, $52.71 \%$ were for rectosigmoidectomy, $18.23 \%$ for left hemicolectomy, $15.95 \%$ for Duhamel-Haddad surgery for lowerings and the last $5.98 \%$ for total colestomy with ileo-rectal anastomosis
(Table 3). In this group, $179(50.98 \%)$ cases were complication - free and $172(49.02 \%)$ had some type of clinical or surgical problem. Of these, the Duhamel-Haddad technique was more prone to complications than anterior retosigmoidectomy and left hemocolectomy. 
TABLE 3 - Techniques employed in 351 elective operations

\begin{tabular}{lcc}
\hline Surgical techniques & $\mathrm{n}^{\circ}$. & $(\%)$ \\
\hline Anterior Retosigmoidectomy Anterior & 185 & $\mathbf{( 5 2 , 7 1 )}$ \\
Left Hemicolectomy & $\mathbf{6 4}$ & $\mathbf{1 8 , 2 3}$ \\
Duhamel Haddad & 56 & $\mathbf{1 5 , 9 5}$ \\
TotalColectomy & $\mathbf{2 1}$ & $\mathbf{5 , 9 8}$ \\
Other Surgeries & $\mathbf{2 5}$ & $\mathbf{7 , 1 2}$ \\
Subtotal colectomy with ascending rectal anastomosis & 11 & 3,13 \\
Lowering surgery acc. Cutait & 4 & 1,14 \\
Left hemicolectomy, colostomy and mucosal fistula & 3 & 0,85 \\
Loop transversostomy & 2 & 0,57 \\
Chambouleyron surgery & 2 & 0,57 \\
Sigmoidectomy, colostomy and mucosal fistula & 1 & 0,28 \\
$\quad$ Simonsen surgery & 1 & 0,28 \\
Tangencial sigmoidostomy & 1 & 0,28 \\
\hline \multicolumn{1}{c}{ Total } & 351 & $\mathbf{1 0 0 , 0}$ \\
\hline
\end{tabular}

In 185 rectosigmoidectomies, 105 (566.76\%) evolved without complications.

Anastomotic dehiscence was the most frequently encountered among surgical complications, occurring in 28 $(15.14 \%)$ cases, of which $22(11.9 \%)$ stayed blocked and 6 $(3.24 \%)$ progressed with peritonitis (Table 4$)$. All 22 patients with blocked anastomotic dehiscence treated by conservative methods had a good post-surgery evolution. The ones with peritonitis, however, had to be submitted to emergency laparatomy for rectum burying and terminal colostomy in 4 of them and in the other two, for a new dehiscence suture with loop transversostomy.

TABLE 4 - Surgical complications in 185 anterior retosigmoidectomies

\begin{tabular}{lcc}
\hline Complications & $\mathbf{n}^{\mathbf{0}}$ & $\mathbf{( \% )}$ \\
\hline Anastomotic Dehiscence & 28 & 15,14 \\
$\quad$ blocked & 22 & 11,90 \\
$\quad$ with peritonitis & 6 & 3,24 \\
Incisional hernia & 13 & 7,02 \\
Dehiscence of the abdominal wall & 8 & 4,32 \\
Anastomotic stenosis & 5 & 2,70 \\
Pre-sacral Abcess & 3 & 1,62 \\
Intestinal obstruction by bridas & 3 & 1,62 \\
$\quad$ On 14 $4^{\text {th }}$ day post-surgery & & \\
On 30 $0^{\text {th }}$ day post-surgery & & \\
$\quad$ After 1 year & 2 & 1,08 \\
Temporary alteration of fecal continence & 1 & 0,54 \\
Anastomotic bleeding to the colo lumen & \multicolumn{2}{c}{} \\
\hline Total & $\mathbf{6 3}$ & $\mathbf{3 4 . 0 5}$ \\
\hline
\end{tabular}

Considering the 64 left hemicolectomies, 35 $(54.69 \%)$ progressed free of complications while $29(45.31 \%)$ had clinical-surgical problems, which in $9(* 14.06 \%)$ patients were anastomotic dehiscence, $7(77.78 \%)$ blocked and 2 $(22.22 \%)$ evolving to peritonitis. Anastomotic stenosis occurred in 2 patients $(3.12 \%)$, alterations in fecal continence in $6(9.37 \%)$ and $4(6.25 \%)$ died (Table 5). Of the complications in this group, 7 patients had anastomotic dehiscence, of which 5 were clinically treated and 2 needed surgical draining of the pelvic compartment and loop transversostomy. Two patients with anastomotic dehiscence with peritonitis needed emergence laparotomy surgery for rectum burying and colostomy. 
TABLE 5 - Surgical complications in 64 left hemicolectomies

\begin{tabular}{lcc}
\hline Surgical Complications & No. & $(\%)$ \\
\hline Anastomotic Dehiscence & $\mathbf{9}$ & $\mathbf{1 4 , 0 6}$ \\
With peritonitis & 2 & \\
Blocked & 7 & \\
$\quad$ with retro-vaginal fistula & 1 & \\
Anastomotic stenosis & $\mathbf{2}$ & $\mathbf{3 , 1 3}$ \\
Abdominal wall dehiscence & 4 & $\mathbf{6 , 2 5}$ \\
Incisional hernia & $\mathbf{2}$ & $\mathbf{3 , 1 3}$ \\
Intestinal obstruction by bridas & $\mathbf{3}$ & $\mathbf{4 , 6 8}$ \\
On the 12 $2^{\text {th }}$ day post-surgery & 1 & \\
On the 30 & 1 & \\
After 6 months & 1 & $\mathbf{9 , 3 7}$ \\
Fecal continence alteration & $\mathbf{6}$ & $\mathbf{9 , 3 7}$ \\
$\quad$ Temporary & 4 & \\
Definitive & 2 & \\
Hemoperitoneum & $\mathbf{2}$ & $\mathbf{3 , 1 3}$ \\
Bleeding of sacral vessels & 1 & \\
Bandage escape in inferior mesenteric artery & 1 & \\
\hline Total & $\mathbf{1}$ & $\mathbf{1 , 5 6}$ \\
\hline
\end{tabular}

In the 351 elective surgery, $56(15.95 \%)$ were through the Duhamel-Haddad technique, of which 15 $(26.79 \%)$ did not show complications. General complications, of the type common to colorectal surgery, occurred in 6 patients $(10.71 \%)$, complications related to lowering surgery were present in $36(64.27 \%)$ cases and the ones specific to the Duhamel-Haddad technique in 14 patients (25\%) (Table 6). One patient with anastomotic dehiscence with peritonitis was submitted to a new intervention to undo the operation, bury the rectum and construct a terminal colostomy. Anastomotic stenosis occurred in 3 cases (5.36\%), all needing surgical amplification. As to fecal continence, 18 patients evolved with " urgent" defecation, but only producing feces in small quantities several times during the day during the first post-surgery months. In 7 these symptoms did not regress. Five patients $(8.92 \%)$ showed sexual dysfunctions, with ejaculation loss in 4 and erection in one. Dehiscence of the rectal segment occurred in 2 patients $(3.57 \%)$ who needed a new surgical procedure for a new segment suture and construction of a loop transversostomy. Rectal segment fecaloma occurred in 8 patients $(14.28 \%)$ and necrotic ischemia of the lowered colon in $5(8.92 \%)$.

TABLE 6 - Clinical-surgical complications in 56 Duhamel-Haddad operations

\begin{tabular}{lcc}
\hline Complications & $\mathbf{n}^{\mathbf{0}}$ & $\mathbf{\%}$ \\
\hline General & & \\
Urinary tract infection & 2 & 3,57 \\
Intestinal obstruction by bridas & 1 & 1,79 \\
Incisional hernia & 1 & 1,79 \\
Abdominal wall dehiscence & 1 & 1,79 \\
Pneumonia & 1 & 1,79 \\
& & \\
Related to lowering operations & & \\
Fecal continence alteration & 18 & 32,14 \\
$\quad$ Temporary & 7 & 12,50 \\
$\quad$ Definitive & 5 & 8,92 \\
Sexual dysfunction (erection/ejaculation) & 5 & 8,92 \\
Ischemia and necrosis of the lowered colon & 1 & 1,79 \\
Pre-sacral abcess & & \\
& & \\
Specific to the Duhamel-Haddad operation & 8 & 14,28 \\
Rectal segment fecaloma & 3 & 5,36 \\
Anastomotic stenosis & 2 & 3,57 \\
Dehiscence of rectal segment & 1 & 1,79 \\
Anastomotic dehiscence with peritonitis & $\mathbf{5 6}$ & $\mathbf{1 0 0}$ \\
\hline Total & & \\
\hline
\end{tabular}


Of the 21 total colectomies, 9(42.86\%) evolved without complications. In the remaining ones, anastomotic dehiscence occurred in $9(42.86 \%)$, of which $2(22.22 \%)$ stayed blocked and of the $7(77.78 \%)$ with peritonitis, 4 (44.44\%) progressed to sepsis and death (Table 7).

TABLE 7 - Surgical and clinical complications in 21 total colectomies

\begin{tabular}{lcc}
\hline Complications & $\mathbf{n}^{\mathbf{0}}$ & $\%$ \\
\hline Anastomotic Dehiscence & $\mathbf{9}$ & $\mathbf{4 2 , 8 6}$ \\
Blocked & 2 & \\
With peritonitis & 7 & \\
Sepsis and death & 4 & \\
Incisional Hernia & 1 & $\mathbf{4 , 7 6}$ \\
Temporary Alteration of fecal continence & 1 & $\mathbf{4 , 7 6}$ \\
Pneumonia & 1 & $\mathbf{4 , 7 6}$ \\
\hline Total & 12 & $\mathbf{5 7 , 1 4}$ \\
\hline
\end{tabular}

For the treatment of ileorectal anastomotic dehiscence with peritonitis, dehiscence suture and loop ileosotomy were the operations mostly utilized.

The non-parametric Kruskal Wallis test was used to analyze and compare elective surgeries according to the severity of complications, showing a significant difference $(\mathrm{p}<0.001)$. The post hoc Dunn test was used to specify the differences, which showed the Duhamel Haddad technique as having significantly more severe complications than anterior retosigmoidectomy and left hemicolectomy; total colectomy was characterized by more serious complications than anterior retosigmoidectomy.

Of the 79 emergency exploratory laparactomies, 53 $(67.09 \%)$ needed intestinal resection and $26(32.91 \%)$ did not. Of the latter, $23(88.45 \%)$ resulted in sigmoid or rectum suture (with or whitout proximal colostomy), volvulus reduction (with colostomy or colon fixation to the parietocolic wall), or fecaloma draining. In the three remaining laparotomies $(11.55 \%)$, an ileostomy or colostomy was the procedure of choice.

In the 53 exploratory laparotomies with intestinal resection, sigmoidectomy with colostomy and rectal burying was the most common operation (45.28\%) followed by left hemicolectomy also with colostomy and rectal burying (11.32\%), sigmoidectomy with colostomy and mucosal fistula $(9.43 \%)$ and total colectomy with ileostomy and rectal burying $(7.55 \%)$.

Emergency operations, according to the degree of complication, were analyzed and compared by the nonparametric Mann Whitney test, which did not show statistically significant differences.

\section{Post-surgery evolution}

Of 430 patients operated on, $268(62.33 \%)$ evolved without recurrence, $71(16.51 \%)$ had recurrent intestinal constipation and 91 could not be evaluated for different causes. Some died, others remained with a certain type of stoma and yet others could not be followed for failing to return as scheduled.

Patients (185) submitted to retosigmoidectomy had post-surgical following in 167 cases $(90.27 \%)$. Of these, 30 (18.0\%) had recurrent intestinal constipation and 27 (16.17) were treated in a conservative manner with laxatives and a diet. The three remaining ones $(11.11 \%)$ were submitted to subtotal colectomy with descending ileoanastomosis, to left colectomy and to subtotal colectomy with rectalascending anastomosis.

Of the 30 patients submitted to anterior retosigmoidectomy, $25(83.33 \%)$ showed recurrence during the first two years post-surgery. The 137 recurrence-free patients had ambulatory follow ups; 127(92.70\%) in the first 5 years, of which $85(62.04 \%)$ for two years and one for 19 years.

Sixty four patients were submitted to left hemicolectomy, and $56(87.5 \%)$ had post-surgery follow up. Of these $22(39.30 \%)$ showed recurrent intestinal constipation and were treated in a conservative manner. In 16 of these $(72.72 \%)$ recurrence was during the first two years post-surgery. Thirty four patients did not show recurrence and $79.41 \%$ were followed up to five years.

The Duhamel-Haddad technique was used in 56 patients and $48(85.70 \%)$ had post-surgery follow up. Of these $8(16.66 \%)$ showed recurrent intestinal constipation, 4 detected in the first two years and the other four, after ten years. The patients were treated in a conservative manner. Fourteen patients $(25 \%)$ had more than ten years follow up.

Of the 21 patients submitted to total colectomy, 14 $(66.66 \%)$ evolved without symptom recurrences, six $(28.57 \%)$ were lost to surgical follow up and one showed recurrence with megaileo.

Evolution of patients who survived emergency surgery shows that $10(12.66 \%)$ remained with stomas and $30(37.97 \%)$ did not have clinical follow up. Seven patients $(8.86 \%)$ had a new surgery to reconstitute intestinal transit and $3(3.79 \%)$ for megacolon resection.

\section{Discussion}

It is general consensus that megacolon treatment is to be surgical. Conservative treatment being reserved to oligosymptomatic cases with moderate ectasia, functionally compensated and with spontaneous intestinal exonerations or with the help of hygiene-dietetic care or judicious use of laxatives. Clinical treatment is also indicated in surgery contra-indicated cases like decompensation cardiopathies, pregnancy, malnutrition cachexia secondary to megaesophagus..$^{22-24}$

Surgical treatment in Chagas megacolon is not meant to cure the disease, since it is incurable and not restricted to the intestine, but to cure constipation and for prophylaxis against complications as fecaloma and sigmoid volvulus.

Easily conducted surgical techniques should be available to adequately trained surgeons and show low or absent recurrence indexes. In the present report, four elective 
operations mostly used were singled out:anterior retosigmoidectomy $(52.71 \%)$, left hemicolectomy $(18.23 \%)$, Duhamel-Haddad operation( $15.95 \%$ ) and total colectomy (5.98\%).

Retosigmoidectomy has been utilized since 1955 by surgeons of the Department of Surgery of the Faculty of Medicine of Ribeirao Preto-n USP, led by Ferreira Santos and Carril, who already in their first work considered this as a procedure of choice. ${ }^{25-27}$ At that time, retosigmaoidectomy with colorectal anastomosis, without previous proximal colostomy, showed high fistula (56\%) and stenosis (25\%) indexes, which were severe and of difficult and lengthy solution, in contrast to $10.9 \%$ and $4.0 \%$, respectively, when previous colostomy is used..$^{28,29}$

The results with retosigmoidectomy have been improved over the years, in parallel with other advances in medicine, not only in relation to better surgical techniques available to surgeons, but also due to better intestinal and general preparation of patients and technological advances like equipment for mechanical anastomosis, suture threads and antimicrobial drugs.

Anterior retosigmoidectomy is an operation, which: 1- does not imply perineal complications and shows low death indexes; 2- allows removal of the full ectasis region of the sigmoid and rectum in a variable extension; 3 -is conducted in only one surgical event and with the availability of circular staplers colorectal anastomoses are low and secure; 4- is a rational surgery for Chagas megacolon as far as it alleviates intestinal constipation ;5 does not need manipulation of the sphyncteral system and hardly originates sexual or urinary disturbances; and 6allows a new intervention, should it be needed, easily attained in cases of stenosis, dehiscence, fistulas or recurrences. The improved results are due to factors added over the years to the original technique, such as rectal lower anastomosis, with wider proctectomies and posterior-end to side anastomosis utilizing staplers. Although satisfactory the results with anterior retsigmoidectomy do not address all cases of megacolon.

The Duhamel Haddad Tehnique is a relatively simple procedure able to be used by the average surgeon familiar with colorectal surgery. However, like in all other lowering operations, diverse types of complications, proportional to the surgeon's skill and his knowledge of technical details, may follow it. ${ }^{30}$

In the 1970s, surgeons of the Surgery Department of FMRP-USP, reported their preference for the Cutait and Duhamel-Haddad technique. ${ }^{31}$ Modifications proposed by Haddad et al. ${ }^{10}$, improved the classical Duhamel procedure because maintenance of perineal colostomy offers more security, not only for allowing observation of the circulatory conditions on the lowered segment, but also because it favors spontaneous coalescence between colon and rectum promoting better conditions for the retarded colorectal anastomosis. It also prevents contamination in the pelvic cavity when colorectal dehiscence occurs, because fecal material is deviated to the exterior. Correct procedures in the second operatorial phase are important to secure good late surgical results. Incomplete section of the septum promotes stenosis and fecalomas
The mortality index in the Duhamel-Haddad technique shown in this report is null, but morbidity was much higher $(73.20 \%)$ than the $42 \%$ reported by Haddad,1968, Medeiros et al. (1980) 34\%; Souza \&Esper (1985), 32.39\%, Habr-Gama et al.( 1982), 39,9\%; Moreira (1986), 30.57\%; Pinheiro (1990), 64\% and Gama et al. (1986), $32.84 \% . .^{24,30,32-36}$

In contrast to retosigmoidectomy, the DuhamelHaddad operation shows complications not only related to the lowering procedure but also other, considered specific.

Globally compared to other elective surgeries, Duhamel-Haddad showed statistically significant higher complication percentages, favorably influenced by the specific ones.

Several factors must be considered in analyzing the Duhamel -Haddad technique: 1- the perineal colostomy discomfort and the waiting period for its resection done on average in the $7^{\circ}$ day post surgery; 2 - the complex resection of the perineal colostomy may favor occurrence of colorectal anastomotic dehiscence and stenosis; 3 - increased hospital stay due to the second surgical event; 4- medical costs and the society reintegration period of the patient.

In this study, the Duhamel-Haddad technique showed lower recurrence of intestinal constipation when compared to anterior retosigmoidectomy and left hemicolectomy. However, since the 1990s the use of this procedure has been gradually reduced as a consensual decision of the Coloproctology staff at the Surgery Department due to the poor results. The difficulties in the recurrent megacolon in a patient operated by the Dhuamelhaddad technique in addition to sexual complications were important factors weighing in this decision. The option was to consciously "risk" having precocious recurrences mostly manageable by clinical measures in place of the current complications. This alternative and the satisfactory results obtained in anterior retosigmoidectomy led the Duhamel-Haddad technique to loose its place as a first choice.

The procedure proposed by Habr-Gama and Reis Neto, easily executed in one surgical event and employing mechanical sutures has been producing clinical, morphological and functional results, which although recent promote it as an alternative to the classical Duhamel Haddad. In addition the retosigmoidectomy with immediate posterior end-to side mechanical colorectal anastomosis may also be done by laparoscopy. ${ }^{19}$

Among the four elective procedures discussed in this report, left hemicolectomy has been used in 64 patients $(18.23 \%)$ and total colectomy with ileorectal anastomosis in 21 patients $(5.98 \%)$. As expected, these procedures were indicated in patients having extensive colonic dilatation, pre-surgically documented by radiographic exams and/or intra-surgery judgement and decision. When compared to the other techniques, left hemicolectomy showed significantly higher recurrence percentages .

The height of colorectal anastomosis is not registered in the patient records, but since it is a procedure 
with more extensive colon resection, the rectum becomes larger than it is desirable and recurrences are more common.

In total colectomy, the colorectal anastomotic dehiscence, when present, is more serious demanding another surgical intervention. But even with total colectomy there was one patient with recurrent megaileo.

The main complications in megacolon described in this report were the sigmoid volvulus and fecaloma, main factors in emergency surgery decisions. Heterogeneous teams on duty, not always specialists in coloproctology, conducted most emergency surgeries according to recognized standards. ${ }^{23,25,37-52}$ The post-surgery evolution in these emergency cases was poor, with 28 deaths(35.44\%). At the operation end, 50 patients had stomas, 23 died, 10 had ambulatory following and 17 did not keep return schedules. These results could possible be improved by more precise diagnostics and treatment of megacolon, thus preventing emergency complications.

Recurrent intestinal constipation in late postsurgery should not be considered a complication but a natural disease evolution. In mega colon all the procedures are palliative measures and are subject to recurrence, the diffuse neuronal lesion being all over the large intestine. ${ }^{53}$ Long term follow up for these patients is a difficulty encountered by several authors. Not only are the patients from low -income groups but in many cases they live far away from the places where they were treated. These conditions prevent recurrence identification, which is made more complex by lack of uniform classification criteria . Thus, is the recurrence clinical, radiographic, manometric or of intestinal motility ? $^{45}$

In this study recurrence was considered by recrudescing intestinal constipation, which was present in 25 patients $(14.97 \%)$ submitted to anterior retosigmoidectomy and after the first two years, in 4 patients $(8.33 \%)$ after the Duhamel-Haddad procedure and in 16 (28.57\%) after left hemicolectomy.

It is possible to conclude from this study that there is not a single model for all cases. The lengths of the colon and rectum, the clinical peculiarities in each patient are distinct variables and they should be met by the surgical technique chosen.

Surgical treatment of megacolon (fecaloma and volvulus) may vary according to the general clinical conditions of the patient, but mainly, based on the surgeon decision faced with the intra-surgery findings.

Currently, functional tests like anorectal manometry and similar, used in anal and pelvic physiological studies should be helpful to define surgical and post -surgical criteria for the treatment of Chagas megacolon. A presurgery method to evaluate the level of rectum neuronal destruction would be a ideal guideline in the choice of procedure. Anterior retosigmoidectomy is chosen in cases where the rectums are not appreciable dilated or neuraly destroyed. A lowering procedure, Duhamel type in one surgical event and using the circular stapler, would be indicated in cases with high dilatation and neuronal destruction.

However, more important than elaborated surgical techniques, physical, social and psychic patient sufferings, the fight to eradicate Chagas disease transmission exclusively through political-administrative and public health measures should be the great conquest of this starting century.

\section{Conclusions}

Based on the results reported it is concluded that :

1- left hemicolectomy showed higher intestinal constipation recurrence when compared to other procedures; 2- anterior retosigmoidectomy compared to the Duhamel-Haddad technique showed less complications but a larger intestinal constipation recurrence; 3- emergency operations to treat volvulus and fecaloma show high morbimortality, need intestinal resections, stomas and new surgery.

\section{References}

1. Almeida AD. Asigmoidectomia abdominal no tratamento do megacólon. Rev Paul Med. 1963;62:349-60.

2. Andrade JI, Queiroz AO, Sobrinho RC, Guimarães VP, Ubinmha AF, Zanaga AR, Gomes A. Volvo do sigmóide: Considerações sobre o tratamento de 44 casos. Rev Bras Cir. 1980;70:155-9.

2. Raia A, Campos OM. O tratamento do megacólonEstudo do follow up de várias técnicas adotadas. Rev Med Cir. 1948;8:287-91.

3. Ria A, Campos OM. A evolução do emprego das colectomias no tratamento cirúrgico do megacólon. Rev Paul Med. 47:29-38.

4. Correa Neto A. Tratamento cirúrgico do megacolo pela ressecção dos chamados esfíncteres funcionais do intestino grosso. Observação de 5 casos curados. Rev Cir S Paulo. 1934;1:249-93.

5. Etzel E. A esficnterectomia parcial como operação de escolha para a cura do megacolon. Rev Bras Cir. 1936;5:95-112.

6. Cutait De, Figlioni FJ, VBranco PD, Altenfelder P, Speranzini M, Campos SM. Ferreira EAB, Birolini D, Fujimura I, Oliveira MR, Bastos ES. Experiência com o tratamento do megacólon adquirido pela retossigmoidectomia e descrição da técnica da anastomose colo-retal retardada. Rev Ass Med Bras. 1965;11:429-34.

7. Simonsen O, Habr-Gama A, Gazal P. Retossigmoidectomia endoanal com ressecção de mucosa retal. Rev Paul Med. 1960;57:116-8.

8. Bernadedes Oliveira A. Tratamento cirúrgico do megacólon pela operação de Duhamel. Rev Paul Med. 1963;63:283-304.

9. Duhamel B. Une novelle operation de megacolon cologenital: abaissement retro-rectal et transanal du colon et son application possible au traitement de 
quelques autres malformations. Presse Med. 1956;64:2249-50.

10. Haddad J, Raia A, Corrêa Netto A. Abaixamento retroretal do cólon com colostomia perineal no tratamento do megacólon adquirido. Operação de Duhamel modificada. Rev. Bras. Colo-Proct. 1965;15:126-30.

11. Vasconcelos E. Colectomia subtotal e anastomose cecoretal no tratamento de megacolo do adulto. Rev Hosp Clin Fac Med S Paulo. 1964;19:321-7.

12. Capelhuchnick P. Tratamento do megacólon adquirido pela hemicolectomia esquerda. Tese. Faculdade de Ciências Médicas, Santa Casa de São Paulo, 1975.

13. Capelhuchnick P, Prado WS. Hemicolectomia esquerda. In: Raia AA Manifestações digestivas da moléstia de Chagas. 1983;26:235-44.

14. Lins Neto MAF, Cansação CLC, Farias LRC. Anastomose colorretal imediata na operação de Duhamel. Rev Bras Colo-Proct. 1988;8:14-6.

15. Ferreira Santos R. Megacolon and megarectum in Chagas' disease. Proc R Soc Med. 1961;54:1047-53.

16. Habr-Gama A, Bocchini SF, Kiss DR, Sousa Jr. Retossigmoidectomia abdominal com anastomose mecânica colo-retal na parede anterior do reto para cirurgia do megacólon. Tema livre. Rev Bras ColoProct. 1990;10:38.

17. Habr-Gama A, Kiss DR, Bocchini SF, Teixeira MG, Pinotti HW. Megacólon chagásico. Tratamento pela retossigmoidectomia abdominal com anastomose mecânica término-lateral. Resultados preliminares. Rev Hosp Clin Fac Med S Paulo. 1994;49:199-203.

18. Nahas SC. Tratamento Cirúrgico do Megacólon Chagásico pela Retossigmoidectomia abdominal com anastomose mecânica colorretal término-lateral posterior imediata (técnica de Habr-Gama). Tese (livre docência). Faculdade de Medicina da Universidade de São Paulo, 2000.

19. Martins FA, Santos FA, Wiering AP, Souza JVS. Tratamento do megacólon chagásico por via laparoscópica. Rev Bras Colo-Proct. 1995;15:68-9.

20. Reis Neto JA, Pedroso MA, Lipinacci RA, Reis Jr JA, Ciquini AS, Lupinaci RM, Beani Jr A, Farah JFM, Kagohara OH, Simões Neto J, Ramanholi Neto J. Megacolo adquirido - Perspectivas fisiopatológicas para o tratamento laparoscópico. Rev Bras Colo-Proct. 2004;24:49-62.

21. Souza JVS, Carmel APW. Martins G, Souza MMB, Silva MMFM. Colectomia laparoscópica versus minilaparotomia. Estudo comparativo. Rev Bras ColoProct. 1997;17:11-4.

22. Moreira H. Tratamento cirúrgico do megacolo chagásico pela técnica de Duhamel-Haddad. Experiência pessoal. Arq Gastroenterol. 1971;185-90.

23. Moreira H, Rezende JM, Sebba F, Azevedo LF Leite ACA, Soares EP. Megacolo chagásico. Rev Bras ColoProct. 3:152-62.

24. Moreira H. Bases fisiopatológicas para o tratamento cirúrgico do megacolo chagásico. Rev Goiana Med. 1986;32:73-8.

27. Ferreira-Santos R, Carril CF. Acquired megacolon in Chagas's disease. Dis Colon Rectum. 1964;7:353-64.
28. Carril CF. Tratamento cirúrgico do megacólon de causa adquirida. Análise crítica da experiência do Departamento de Cirurgia da Faculdade de Medicina de Ribeirão Preto. Tese (doutorado). Faculdade de Medicina de Ribeirão Preto-Universidade de São Paulo, 1963.

29. Ferreira Santos R, Carril CF. Megacolon chagásico: Experiência do Departamento de Cirurgia da Faculdade de Medicina de Ribeirão Preto da USP. Rev Paul Med. 1962;60:100-8

30. Habr-Gama A, Goffi FS, Raia A, Ferrão SOT, Nagamassa Y. Tratamento cirúrgico do megacolo. Operação de Duhamel-Haddad. Rev Col Bras Cir. 9:25-31.

31. Carril CF, Guimarães AS, Aprilli F. Tratamento cirúrgico do megacolo chagásico. Rev. do Centro Acadêmico Rocha Lima e do Hospital das Clínicas da Faculdade de Medicina de Ribeirão Preto- USP. 1972;5:95-105.

32. Haddad J. Tratamento do megacolo adquirido pelo abaixamento retro-retal do colo com colostomia perineal. Rev Hosp Clin Fac Med S Paulo. 1968b;23:235-53.

33. Medeiros RR, Reis Neto JA, Leoardi LS, Pires AM, Accorroni ME. Estudo comparativo entre as técnicas de Duhamel e Duhamel-Haddad na cirurgia do megacólon chagásico. Rev Paul Med. 1996; 11:61-5.

34. Souza AG, Esper FE. Tratamento cirúrgico do megacolo adquirido.Nossa experiência com 480 casos. Rev Col Bras Cir. 1998;12:13-7.

35. Pinhyeiro HB. Abordagem cirúrgica do megacolo chagásico. Experiência pessoal. Rev Bras Colo-Proct. 1990;1:39-42.

36. Gama RC, Costa JH, Azevedo LF. Tratamento cirúrgico do megacolo chagásico pela técnica de DuhamelHaddad. Experiência no Hospital Geral de Goiânia. Análise de 204 casos. Rev Bras Colo-Proct. 1986;6:848.

37. Habr-Gama A, Simonsen O, Haddad J, Raia A, Corrêa Netto A. Volvo do sigmóide: Considerações gerais e resultados do tratamento conservador pelo esvaziamento endoscópico. Rev Ass Med Bras. 1968;14:287-8.

38. Hashimoto T, Speranzini MB, Lopes ER, Bartolomucci AC, Rocha AColite isquêmica: complicação da cirurgia do megacólon. Rev Paul Med. 1974;84:37-44.

39. Habr-Gama A, Haddad J, Simonsen O, Warde P, Manzione A, Silva J, Ioshimoto M, Cutait D, Raia A. Volvulus of the Sigmoid Colon in Razil: A Report of 230 Cases. Dis Colon Rectum. 1975;19:314-21.

40. Ferreira Santos R, Carril CF, Santos Jr JCM, Guimarães AS, Aprilli F, Gomes DR. Complicações do megacolo adquirido. Rev Ass Med Bras. 1977;23:427-8.

42. Pinheiro HB. Complicações do megacólon chagásico. Padronização de tratamento. Rev Bras Colo-Proct. 1981;1:2-15.

43. Laurence AE. Operação de Hartmann. Rev Bras ColoProct. 1982; 2:28-32.

44. Bakonyi Neto A, Lima JTC, Yassumoto A, Barato E. Volvo de sigmóide após cirurgia de abaixamento do cólon. Apresentação de caso. Rev Bras Colo-Proct. 1984:4:39-41. 
45. Cruz GMG. Megacólon chagásico. Rev Bras ColoProct. 1984;4:87-98.

46. Corbett CEP, Ribeiro Jr U, Prianti MG, Habr-Gama A, Cordeiro F. Tribuna livre: Como eu faço. Rev Bras ColoProct. 1995;15:83-7.

47. Reis Neto JÁ, Quilici FA, Oliveira LAR, Reis Jr JA. Vólvulo de sigmóide. Intubação retossigmoideana descompressiva. Rev Bras Colo-Proct. 1986;6:163-70.

48. Habr-Gama A, Teixiera MG, Vieira MJF, Mileu LF, Laurino Neto R, Pinotti HW. Operação de Hartmann e suas conseqüências.Rev Bras Colo-Proct. 2000;17:5-10.

49. Cordeiro F, Reis Neto JÁ, Souza JVS, Habr-Gama A. Tribuna livre: Como eu faço. Rev Bras Colo-Proct. 2001;21:50-1.
50. Reis LDO, Lombardi AO, Reis ADO, Cardoso EH, Cardoso Filho CAM. Cirurgia de Hartmann: Análise de 41 casos em hospital de referência do norte do Paraná. Rev Bras Colo-Proct. 2001;21:19-22.

51. Santos Jr JCM. Megacólon - Parte II: Doença de Chagas. Rev Bras Colo-Proct. 2002;22: 266-77.

52. Santos Jr JCM. Tópicos controversos - Mitos em Coloproctologia. Rev Bras Colo-Proct. 2004;24:78-90.

53. Henry MACA, Mendes EF, Prado RG, Saad LHC, Gonçalves Jr I, Macedo AR. Megacólon: análise de 200 pacientes submetidos a tratamento cirúrgico. Rev Goiana Méd 1989;35:25-33.

\section{Correspondence:}

Ricardo Luiz Santos Garcia

Avenida 9 de julho, 1818

Jardim América

CEP 14020-170 - Ribeirão Preto, São Paulo

Phone: 1636368356

Conflite of interest: no

FAX: 1636368770

ricardolsgarcia@uol.com.br

\section{How to cite this article:}

Garcia RLS, Matos BMR, Feres O, Rocha JJR. Surgical treatment of Chagas Megacolon. Critical analysis of outcome in operative methods. Acta Cir Bras [serial on the Internet], 2008; 23 Suppl 1. Available from: URL: http://www.scielo.br/acb.

\section{Comments:}

Several surgical procedures were developed for the cure of chagasic megacolon, in part due to the poor knowledge of its physiopathology and frustrating treatment results. The varied operations are characterized by distinct complications, technical complexities and recurrence indexes, but with the advent of videolaparoscopy it is possible to detect new advances in surgical techniques. The therapeutic variety available, in itself justifies this retrospective study, which evaluated the results (symptom recurrence and complications) of the different surgical methods adopted in the treatment of chagasic megacolon. The study conducted by Garcia et al. was adequate in terms of methodology, statistical analysis, presentation and evaluation of results, which in general confirmed literature data with the exception of the higher complication rates detected in the Duhamel-Haddad technique. The conclusions, consistent with the objectives of the investigation and supported by literature data emphasized the higher morbimortality and new operations incidence in emergency cases. They further showed the higher recurrence of intestinal constipation when conservative procedures are adopted like left hemicolectomy and anterior rectosigmoidectomy in comparison to the Duhamel-Haddad technique. However, analysis of videolaparoscopic methods, which represent an important technological advance with reduced morbidity are missing in the study.

\section{Rafael Kemp}

MD, Assistant, Division of Digestive Surgery, Department of Surgery and Anatomy, Ribeirão Preto Faculty of Medicine, University of São Paulo, Brazil. 